\title{
A protein-binding site in the c-myc promoter functions as a terminator of RNA polymerase II transcription
}

\author{
Sadia Roberts, Tracey Purton, and David L. Bentley ${ }^{1}$ \\ Imperial Cancer Research Fund, Lincoln's Inn Fields, London WC2A 3PX, UK
}

\begin{abstract}
Termination of transcription not only allows polymerases that have completed RNA synthesis to recycle, but it also has important functions in transcriptional regulation and in preventing promoter interference. The molecular basis for termination by RNA polymerase II (pol II) is unclear, however. We have identified a termination site in the promoter region of the c-myc gene, whose function correlates with DNA binding by a nuclear factor. When the c-myc gene was transcribed in injected Xenopus oocytes or a HeLa nuclear extract, a fraction of RNA initiated at the first promoter, P1, terminated at two positions, T1A and T1B, which flank the TATA box of the second promoter, P2. T1B is a T-rich sequence that resembles previously identified attenuation sites, but T1A appears to represent a different class of termination site. T1A is situated $\sim 10$ bases upstream of an element that overlaps the P2 TATA box. Mutagenesis of this element affected both the efficiency and the position at which termination occurred. A 28-base sequence including this element caused a low level of termination when inserted into the $\alpha$-globin gene in either orientation. This sequence bound a factor called TBF I (terminator-binding factor), whose binding specificity correlated with T1A terminator function. We suggest that TBF I may function as a pol II termination factor.
\end{abstract}

[Key Words: RNA polymerase II; DNA-binding factor; termination; transcription; c-myc]

Received December 23, 1991; revised version accepted April 20, 1992.

Termination of transcription by RNA polymerase has been observed at the $3^{\prime}$ ends of genes, at attenuation sites within genes, and in their $5^{\prime}$-flanking promoter sequences. Attenuation has been documented in a number of cellular and viral genes transcribed by polymerase II (pol II), where it can be modulated by a variety of stimuli (for review, see Spencer and Groudine 1990). For instance, c-myc expression is down-regulated during differentiation of HL60 and mouse erythroleukemic cells by increasing the efficiency of termination at a site near the end of the first exon (Bentley and Groudine 1986a; Watson 1988). Termination has also been observed in the 5 '-flanking sequences of several genes (McGeady et al. 1986; Connelly and Manley 1989a,b), where it may serve to prevent disruption of transcription complexes by polymerases reading through from upstream promoters. There is evidence that pol II can interfere with the function of promoters through which it transcribes /Adhya and Gottesman 1982; Cullen et al. 1984; Proudfoot 1986; Corbin and Maniatis 1989); however, a specific termination site that functions to prevent such interference has only been conclusively demonstrated in the promoter of rRNA genes transcribed by polymerase I (pol I) (Bateman and Paule 1988; Henderson et al. 19891.
The mechanisms that arrest and release pol II from its template are, in most cases, obscure, although RNA secondary structure, DNA bending, and DNA-binding proteins have all been suggested (Eick and Bornkamm 1986; Kerppola and Kane 1990; Ashfield et al. 1991). On the other hand, termination by pol I is relatively well understood. The polymerase stops $15-25$ bases upstream of short consensus sequences for which cognate DNAbinding factors have been purified from mouse and $\mathrm{Xe}$ nopus (Grummt et al. 1986; Labhart and Reeder 1986; Bartsch et al. 1988; McStay and Reeder 1990). Termination by the mitochondrial RNA polymerase is also caused by a sequence-specific DNA-binding protein (Hess et al. 1991). One case has been reported of pol II termination in response to a naturally occurring proteinbinding element, in the adenovirus major late promoter (MLP). In this promoter the CCAAT box functioned as an orientation-specific termination signal (Connelly and Manley 1989a,b), although the site of termination with respect to the binding site could not be determined accurately. No other consensus sequence with a pol II terminator function in vivo has been clearly defined, with the exception of the $3^{\prime}$ box (Hernandez 1985), which lies $\sim 14$ bases downstream of the $3^{\prime}$ end of the longest small nuclear RNA (snRNA) precursors. It is not known whether the $3^{\prime}$ box functions by binding a termination factor. In genes that produce mRNA, the polyadenyla-

${ }^{1}$ Corresponding author. 
tion signal or histone $3^{\prime}$ processing site is necessary but not sufficient for termination, which may occur $>1 \mathrm{~kb}$ downstream /Citron et al. 1984; Whitelaw and Proudfoot 1986; Logan et al. 1987; Connelly and Manley 1988; Chodchoy et al. 1991). It is not yet clear how these processing sites exert their effects at a distance.

The c-myc gene is transcribed from two promoters, P1 and P2, whose start sites are $\sim 150$ bases apart. Transcription from $\mathrm{P} 2$ but not $\mathrm{P} 1$ is regulated by attenuation at a T-rich sequence called T2 near the $3^{\prime}$ end of the first exon (Bentley and Groudine 1986a, 1988; Eick and Bornkamm 1986; Nepveu and Marcu 1986; Wright and Bishop 1989; Spencer et al. 1990; Roberts and Bentley 1992). A factor called MElal has been implicated in the function of the $\mathrm{P} 2$ promoter as well as termination at $\mathrm{T} 2$ and at the $3^{\prime}$ end of the human complement $\mathrm{C} 2$ gene (Asselin et al. 1989; Hall 1990; Miller et al. 1989; Ashfield et al. 1991). The T2 site of the mouse and human c-myc genes was mapped using transcripts made in injected Xenopus oocytes, and a 95-base sequence 5' of T2 in the human gene was shown to program accurate termination (Bentley and Groudine 1988). The oocyte system transcribes the c-myc gene efficiently and accurately and, unlike mammalian cells, does not rapidly degrade the truncated products of premature termination events. In this paper we have used injected oocytes, as well as a HeLa nuclear extract, to show that a significant fraction of transcripts initiated at the Pl start site also terminates prematurely at two positions, T1A and T1B. Similar observations have been reported by Wright et al. (1991). T1B resembles the T2 attenuator, whereas T1A resembles the terminators for pol $I$ and the mitochondrial polymerase in that it requires a protein-binding element downstream of the site of $3^{\prime}$-end formation.

\section{Results}

\section{Termination of transcription from the P1 promoter}

The possibility that transcription from the P1 promoter is subject to premature termination was initially investigated by analyzing RNA made in Xenopus oocytes microinjected with c-myc plasmids. In the experiment shown in Figure 1B, RNA from oocytes injected with the mouse gene was analyzed by $\mathrm{S} 1$ nuclease and exonuclease VII protection of 3 '-end-labeled probes specific for RNA from the P1 promoter as diagramed in Figure 1A. A similar experiment with the human c-myc gene is shown in Figure 1D. In both the mouse and human genes, a substantial fraction of P1 transcripts apparently terminated at two positions labeled T1A and T1B. Because the nuclease protection mapping data generated by an endonuclease (S1) and an exonuclease agree completely, it is very unlikely that they represent artifactual nuclease cutting. Further support for genuine $3^{\prime}$-end formation at T1A and T1B was obtained by Northern blotting of RNA from injected oocytes fractionated on denaturing acrylamide gels (Fig. 1C). In this experiment two RNA species of $\sim 160$ and 123 bases were detected in oocytes injected with the wild-type mouse c-myc gene (lane P1) but not in oocytes injected with a construct lacking the P1 promoter or in an uninjected control (lanes $\Delta \mathrm{P} 1$ and $\mathrm{UN}$ ). The lengths of these two RNAs correspond to those predicted for transcripts initiated at $\mathrm{P} 1$ and terminated at T1A and T1B, respectively (see Fig. 2). Nuclease protection of uniformly labeled probes overlapping both ends of the RNAs supports the Northern blotting data for the sizes of these short P1 transcripts (data not shown). The RNAs terminated at T1 were synthesized by pol II as shown by their sensitivity to $1 \mu \mathrm{g}$ / $\mathrm{ml}$ of $\alpha$-amanitin (Fig. 1D and data not shown). The results of the 3 '-end mapping experiments are summarized in Figure 2. Although T1 occurs at homologous positions in the mouse and human genes, the sequences differ significantly in this region. T1B corresponds to the sequence TTTTTTT in the mouse gene and TTTAT in the human gene. This abundance of $T$ residues is a feature shared with the $\mathrm{T} 2$ attenuation site. T1A does not appear to resemble previously described pol II termination sites.

The possibility that truncated Pl transcripts arose by the processing of longer RNAs was tested by injecting a 1000 -bp ${ }^{32}$ P-labeled, capped synthetic RNA that included most of exon 1, as well as 425 bases upstream of the P1 start site, into the nucleus of oocytes. (It is not necessary for the RNA to start at the P1 initiation site for T1A and T1B $3^{\prime}$ ends to be made, as shown in Fig. 3A.) After a 20-hr incubation the RNA was reisolated and analyzed by acrylamide gel electrophoresis. No cleavage products were detected, suggesting that processing at $\mathrm{T} 1$ is unlikely (data not shown), although we cannot rule out the possibility that $3^{\prime}$ ends are generated by rapid cotranscriptional processing. For the purpose of this discussion, we refer to the $3^{\prime}$ ends at $\mathrm{T} 1$ as products of termination.

\section{$\alpha$-Globin-promoted transcription terminates at $T 1$ in vitro and in oocytes}

To test whether the $\mathrm{T} 1$ termination site was recognized by a mammalian pol II transcription system, we transcribed this region of the mouse c-myc gene in vitro with a HeLa cell nuclear extract. Because the P1 promoter is very weak in this extract, we used a template in which the P1 promoter and 20 bases downstream of the start site were replaced by the human $\alpha 1$-globin promoter plus 35 bases of globin mRNA sequence. The $3^{\prime}$ ends of transcripts from the globin promoter were mapped by $\mathrm{S} 1$ protection (Fig. 1E). $\alpha$-Amanitin-sensitive pol II transcription terminated at both $\mathrm{T} 1 \mathrm{~A}$ and $\mathrm{T} 1 \mathrm{~B}$, although a relatively diffuse pattern of $3^{\prime}$ ends upstream of TlA was also detected in contrast to the oocyte results. Thus, T1 functions as a terminator in a mammalian transcription system and is independent of the P1 promoter.

T1A differs from most sites of premature termination in that it does not correspond to a run of $T$ residues. We chose to investigate the sequence determinants of termination at this position. A 120 -base fragment $1-20$ to -140 relative to the $\mathrm{P} 2$ start) of the mouse c-myc gene containing TlA but not T1B was inserted into the human $\alpha$ l-globin gene and assayed for termination in injected oocytes. The result in Figure 3A, lane 7, shows 


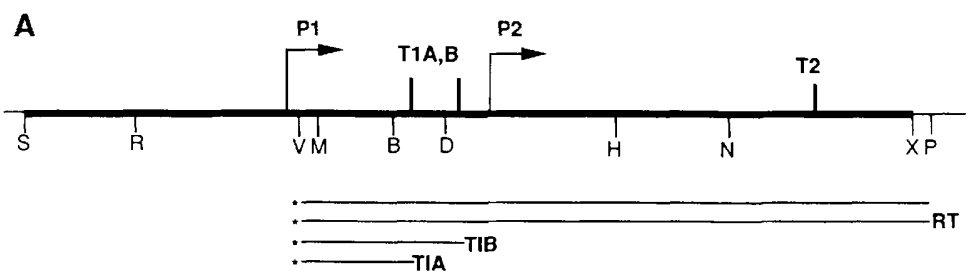

B
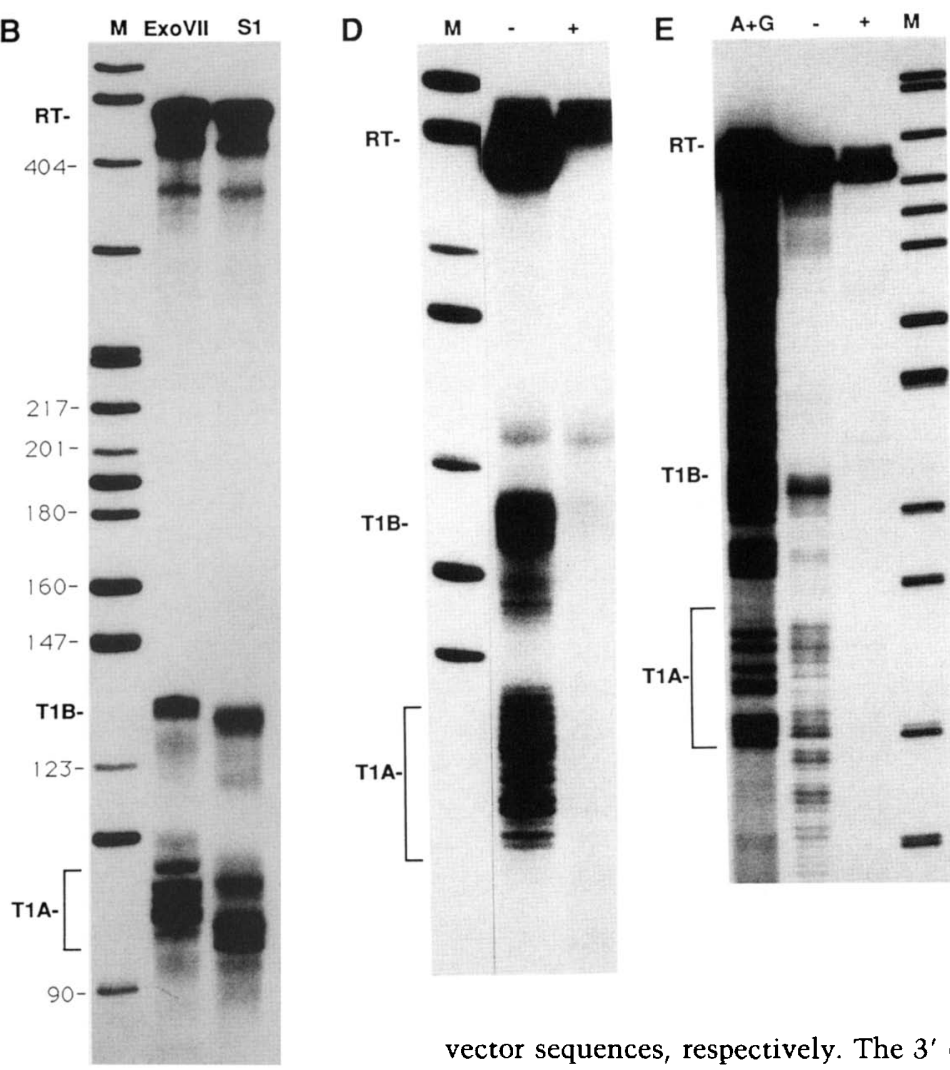

Figure 1. Transcripts from the c-myc P1 promoter terminate prematurely. $(A)$ Map of mouse c-myc exon 1 sequences in pSX943. The $3^{\prime}$-end mapping strategy used in $B$ is diagramed. The promoters $\mathrm{Pl}$ and $\mathrm{P} 2$ and the termination sites $\mathrm{T} 1 \mathrm{~A} / \mathrm{B}$ and T2 are marked, as well as restriction sites for SmaI (S), RsaI (R), PvuII (V), MspI (M),BamHI (B), HindIII (D), HhaI (H), NotI (N), XhoI (X), and PstI (P). The thick and thin lines indicate $c-m y c$ and vector sequences, respectively. The $3^{\prime}$ end of the c-myc sequence corresponds to the XhoI site at +360 relative to $\mathrm{P} 2$. (B) Exonuclease VII protection and S1 protection of mouse c-myc RNA from oocytes injected with pSX943. The probe was a 498-bp PvuII-PstI fragment 3 -end-labeled at PvuII. Readthrough (RT) and terminated (T1A/B) RNAs are marked. The RT band includes renatured probe and is therefore an overestimate of the true amount of RT RNA. (Lane M) MspI-cut pBR322 size markers. $(C)$ Northern blot of mouse c-myc RNA from injected oocytes. RNA was fractionated on

TIA a 5\% denaturing acrylamide gel along with labeled MspI-cut pBR322 markers, electroblotted, and hybridized to a 742-base antisense RNA transcribed from RsaI-cut pSX943. Oocytes were injected with pSX943 (lane $P 1$ ) and pPX490 (lane $\Delta P 1$ ), which lacks P1. (Lane UN) Uninjected oocyte RNA. (D) S1 nuclease protection of human c-myc RNA from oocytes injected with pGC1HR without (-) and with $1+11 \mu \mathrm{g} / \mathrm{ml}$ of $\alpha$-amanitin. The probe was a 160-base XhoI-HindIII fragment containing the 140-base Xhol-NaeI fragment and 20 bases of polylinker. It was 3 '-end-labeled at the XhoI site at position -95 relative to the P2 start site. $(E)$ Termination at T1 in a HeLa nuclear extract. The supercoiled plasmid paPX490 was transcribed in vitro without $(-)$ and with $1+\mid 1 \mu \mathrm{g} / \mathrm{ml}$ of $\alpha$-amanitin and RNA 3' ends mapped by S1 protection with the $210-$ base MspI-HhaI probe (see A) 3'-end-labeled at the MspI site. An A + G Maxam-Gilbert sequencing ladder of the probe is shown.

that this fragment is sufficient to program accurate termination at T1A at a comparable efficiency to the wildtype c-myc gene and, therefore, eliminates the possibility that $3^{\prime}$ ends at T1 A are generated by the nibbling back of T1B RNA. Thus, T1A can operate independently of its natural promoter in vitro and in oocytes and does not require $\mathrm{T} 1 \mathrm{~B}$ or other sequences downstream of position -20 (see Fig. 2).
An element overlapping the P2 TATA box is required for termination at $T 1 A$

The sequence immediately downstream of T1A is the TATA box consensus of the $\mathrm{P} 2$ promoter. The role of this element (TATAAA) in specifying termination was studied by replacing it in the mouse gene with a BgIII site (AGATCT). This mutation, Bgl(TATA), does not disrupt 


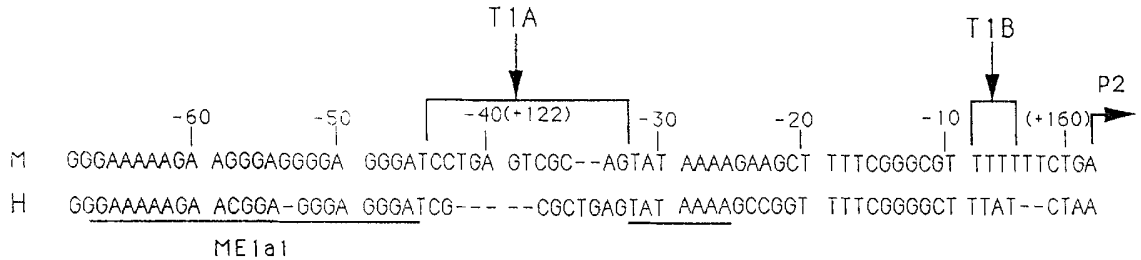

Figure 2. Sequence of $\mathrm{P} 2$ promoter region and positions of termination at $\mathrm{Tl} \mathrm{A} / \mathrm{B}$ in the mouse (M) and human (H) c-myc genes. The binding site for the MElal factor and the TATA box are underlined. Bases are numbered relative to the P2 initiation site, except those in parentheses, which are relative to $\mathrm{Pl}$. the actual termination site but, rather, the sequence immediately downstream of it. When the mutation was assayed in injected oocytes, termination in the $5^{\prime}$ region of $\mathrm{T} 1 \mathrm{~A}, \mathrm{~T} 1 \mathrm{~A} \mid \mathrm{S})$, but not the $3^{\prime}$ region, $\mathrm{T} 1 \mathrm{~A}(\mathrm{~L})$, was severely reduced relative to the wild-type gene (Fig. 3A, cf. lanes 3 and 5 with lanes 4 and 6), whereas T1B was relatively unaffected. Termination was also reduced when the TATA box was similarly replaced in the $\alpha$-globinmyc construct (Fig. 3A, lane 8). A 7-base deletion of the sequence TATAAAA in the P2 promoter of the human c-myc gene abolished all termination at TlA without inhibiting T1B (Fig. 3B). In summary, replacement or deletion of the P2 TATA box caused a large reduction in the extent of termination at T1A in the mouse and human genes. In the mouse gene this effect was confined to the shorter $\mathrm{T} 1 \mathrm{~A} / \mathrm{S})$ class of termination products.

\section{TATA box and 3'-flanking mutations inhibit termination}

Further analysis of the TATA region was performed to define in more detail the elements reponsible for termination at T1A. To distinguish between requirements for a specific sequence versus a region rich in $\mathrm{A}$ and $\mathrm{T}$, two point mutations were made in the fourth position of the TATA box, which altered the sequence TATA to TATT or TATG. When tested in injected oocytes, both point mutations inhibited termination at $\mathrm{T} 1 \mathrm{~A}|\mathrm{~S}\rangle$ but not T1A(L). The TATG mutation was more effective than TATT if T1A is compared with T1B (Fig. 4A). We cannot exclude the possibility, however, that these mutations also affect termination efficiency at T1B.

We have established that a fragment comprising bases -140 to -20 relative to the $\mathrm{P} 2$ initiation site is sufficient for termination at T1A (Fig. 3A, lane 7). This fragment includes 6 bases $3^{\prime}$ of TATAAAA, which could play a role in specifying termination. This sequence, GAAGCT, was changed to an NcoI site, CCATGG, and the mutation was tested in oocytes. The TATA-Nco mutation inhibited termination at $\mathrm{T} 1 \mathrm{~A} / \mathrm{S})$ as effectively as complete replacement of the TATA box in the Bgl(TATA) construct (Fig. 4A). None of our mutations of the mouse $c-m y c$ gene significantly reduced production of the T1A(L) RNA, whereas they all inhibited T1A(S). We do not know how T1A(L) RNA is produced, but it does not appear to be a precursor of T1A(S) RNA, as mutation of the sequence $7-12$ bases beyond the $3^{\prime}$ end of $\mathrm{T} 1 \mathrm{~A}(\mathrm{~L})$ in the TATA-Nco mutant inhibited production of the $\mathrm{T} 1 \mathrm{~A} / \mathrm{S})$ transcript. In summary, these results define a sequence-specific element that overlaps the TATA box and 6 bases of $3^{\prime}$-flanking sequence that is necessary for efficient termination of transcription at $\mathrm{T} 1 \mathrm{~A}(\mathrm{~S})$.

Because the sequences involved in termination at T1A and initiation at P2 overlap one another, we investigated whether termination only occurred in the presence of an initiation complex at P2. Initiation at the mutant P2 promoters was measured relative to $\mathrm{P} 1$ by $5^{\prime}$-end mapping (Fig. 4B). The Bgl(TATA) mutation, which completely replaces the TATA box, abolished P2 promoter activity while the TATA-Nco mutation had no detectable effect. The protected band of $\sim 140$ bases in the $B g l$ (TATA) lane corresponds to $\mathrm{Pl}$ transcripts protected by the wild-type $\mathrm{P} 2$ probe, which is cleaved at the 6 -base mismatch. The TATT and TATG mutations both reduced $\mathrm{P} 2$ promoter strength relative to $\mathrm{Pl}$ without affecting the accuracy of initiation, although the effect of the TATT mutation was weak. In summary, the data in Figure 4 suggest that there is no correlation between P2 promoter strength and termination at T1A. This point is illustrated best by the TATA-Nco mutation, which severely reduced T1A termination but had a negligible effect on promoter strength. These results demonstrate that an active initiation at P2 is not sufficient to cause termination at T1A.

\section{The element downstream of T1A determines the position of termination}

The experiments described above show the importance of a sequence element that overlaps the $3^{\prime}$ end of the TATA box for efficient termination at T1A. We have investigated whether this element also determines the position of $3^{\prime}$-end formation. For this purpose, the distance between T1A and the element was increased by inserting 10 bases, TCAGATCTGC, in front of the first $\mathrm{T}$ of the TATA box and analyzing termination in oocytes (Fig. 5). The efficiency of termination was unaffected by the insertion. Interestingly however, the site of 3 '-end formation was shifted $\sim 10$ bases downstream into the inserted sequence. Termination therefore occurred at approximately the same distance upstream of the TATA box as in the wild-type gene. These experiments show that termination can occur in a sequence apparently unrelated to its natural site. Furthermore, they suggest that an element downstream of T1A plays a role in determining where polymerases arrest.

\section{Effect on termination of elements upstream of T1A}

We have also tested whether the sequences immediately upstream of T1A function in termination of transcrip- 

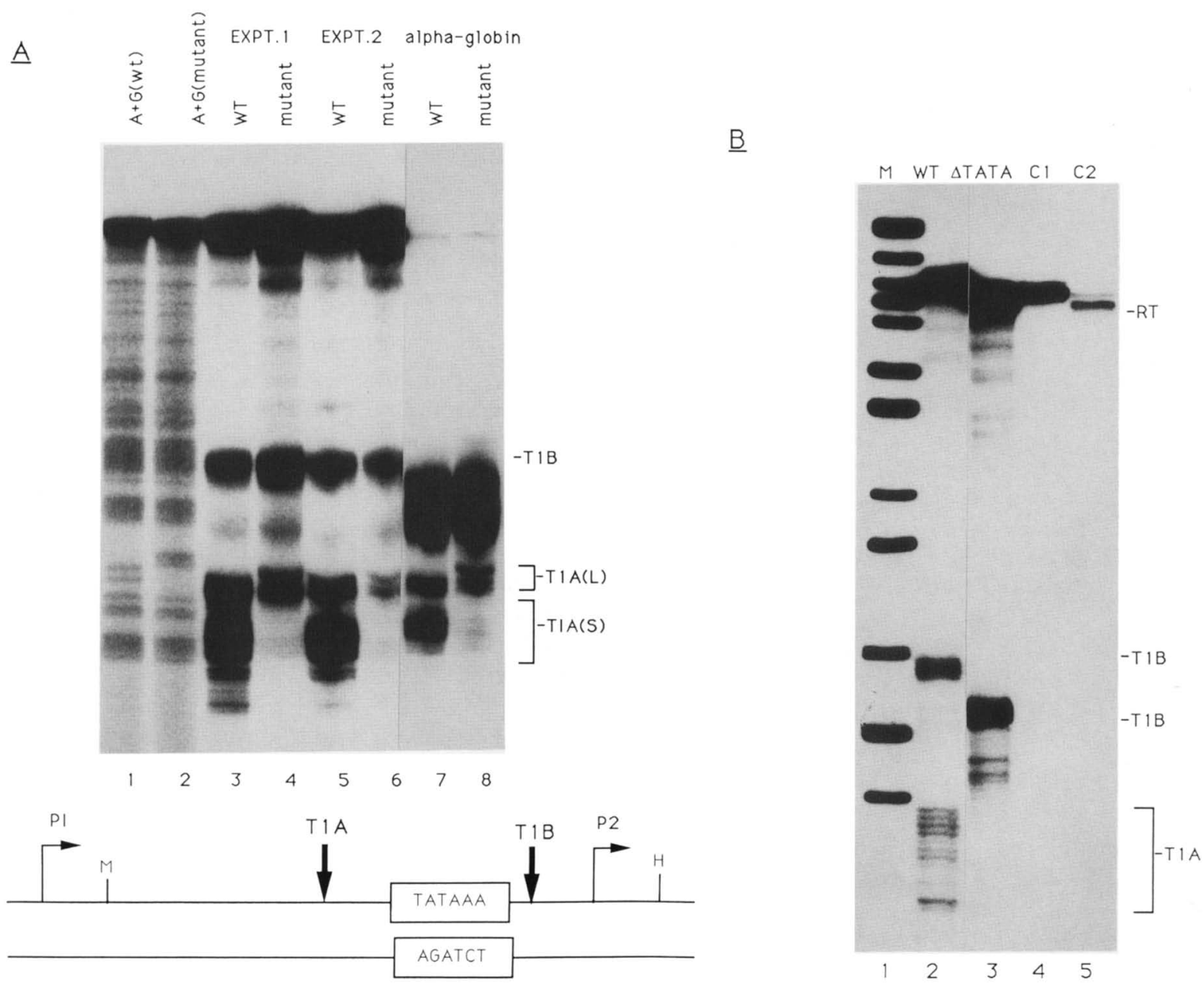

Figure 3. Mutation of the P2 TATA box reduces termination at T1A in the mouse and human c-myc genes. $(A) \mathrm{S} 1$ protection of RNA from oocytes injected with wild-type and mutant mouse c-myc genes (see diagram). (Lanes 1,2) A + G sequencing ladders of $3^{\prime}$-endlabeled 210-base MspI-HhaI probes. The TATA box in the wild-type sequence is marked. In experiments 1 and 2, different batches of oocytes were injected. The plasmids injected were pSX943 (lanes 3,5) and pSX943/Bgl(TATA) (lanes 4,6). In lanes 7 and 8, transcripts of the $\alpha$-globin-myc chimeric plasmids p $\alpha$ T1A-120 and p $\alpha$ T1A-120Bgl(TATA) were analyzed with the MspI-HhaI probes. T1A(L) and $\mathrm{T} 1 \mathrm{~A}|\mathrm{~S}\rangle$ refer to long and short components of T1A, respectively. Transcripts reading through the T1A site protect a fragment of 118 bases, which has been nibbled by the $\mathrm{S} 1$ nuclease to give a diffuse band. (Diagram) The P2 promoter region with the sequences of the wild-type and mutant TATA boxes and the positions of $M s p I(M)$ and $H h a I(H)$ sites. $(B)$ S1 protection of RNA from the wild-type and TATA deletion mutant human c-myc genes. Injected plasmids were pGClHR (lane 1) and pmyc $\Delta$ TATA (lane 2), which has a 7-base deletion. The probes were $X$ hoI-XhoII fragments derived from the two plasmids 3 '-end-labeled at the XhoI site at position -95 relative to $\mathrm{P} 2$ in the wild-type gene. In lanes 4 and 5, wild-type and mutant probes were hybridized to uninjected oocyte RNA as a negative control. TIA, T1B, and readthrough $(\mathrm{RT})$ are marked.

tion. To the $5^{\prime}$ side of T1A lies the GA-rich binding site for the MElal factor (Asselin et al. 1989; Hall 1990; see Fig. 2). The importance of this sequence for T1A termination in oocytes was tested by making a 14-base deletion between positions -62 and -49 relative to the $P 2$ start (Fig. 6). Termination at T1A and T1B was not reduced nor was its position affected by this deletion. (The apparent increase in termination was not reproducible.) Clearly, the sequences immediately upstream of T1A do not have an appreciable affect on termination at this site in oocytes. However, because we do not know whether the MElal-binding activity exists in oocytes, we cannot eliminate the possibility that this factor plays some role in termination in mammalian cells. Our deletion recreates a GA-rich sequence which, although distinct from the MElal sequence, has not been ruled out as a possible MElal-binding site. A binding site for the E2F factor lies immediately upstream of the MElal sequence. This sequence was also mutated, and preliminary experiments did not reveal any effect on termination at $\mathrm{Tl}$ /data not shown).

\section{A 28-base element is sufficient to signal low-level termination}

Having shown that the sequences downstream of -20 

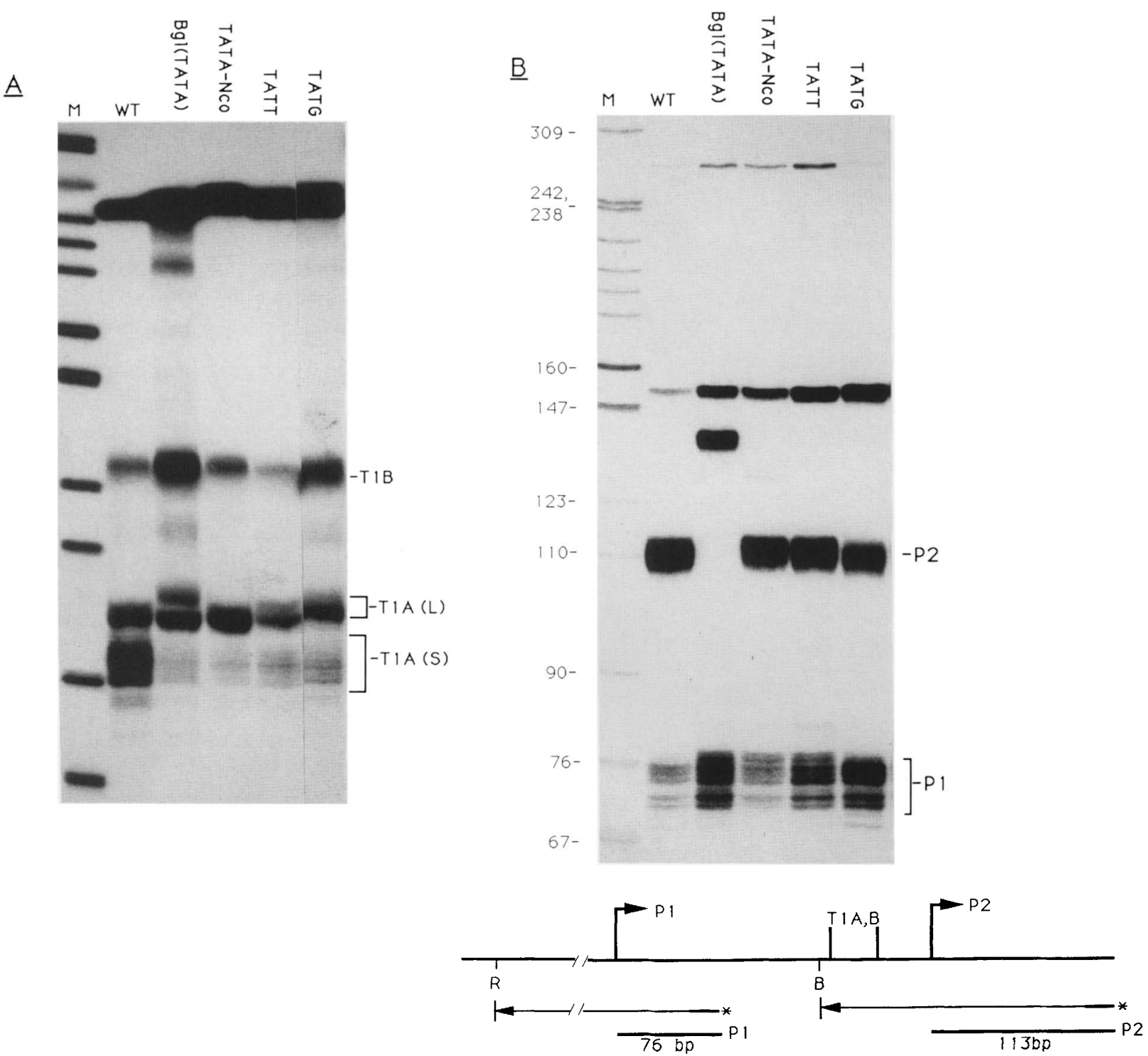

Figure 4. Effect of mutations of the P2 TATA region on initiation and termination. (A) Termination at T1 was assayed by S1 protection of MspI-HhaI probes (see Fig. 1A) from the respective plasmids. Oocytes were injected with pSX943 (WT) and four mutants as indicated. $(B)$ The $5^{\prime}$ ends of the RNAs analyzed in $A$ were mapped by $\mathrm{S} 1$ protection as diagramed below. Restriction sites for $R s a \mathrm{I}$ $(\mathrm{K})$ and BamHI (B) are marked. Single-stranded 5'-end-labeled probes were made from the wild-type c-myc template M13 SX943. The positions of $\mathrm{P} 1$ - and $\mathrm{P} 2$-initiated transcription are marked.

and the MElal element between -49 and -62 (see Fig. 2) are not essential for T1A function, we tested whether a 28 -bp sequence from -20 to -47 was sufficient to signal termination. This short segment of the mouse c-myc gene containing T1A, the TATA box, and 6 bases downstream was inserted into the $\alpha 1$-globin in both orientations, and the constructs were assayed by S1 protection of single-stranded 3'-end-labeled probes (Fig. 7). A control for artifactual S1 cleavage within the c-myc element is shown in lane 6 , which has been overexposed. A low level of $3^{\prime}$-end formation was detected in the globin sequence downstream of the HindII site where the c-myc sequences were inserted (lane 1). Additional 3' ends were detected within the $\mathrm{c}-\mathrm{myc}$ element in both orientations (lanes 2-4). Two sets of $3^{\prime}$ ends were observed when tandem copies of the oligonucleotide were inserted in the sense orientation (lane 3). The $3^{\prime}$ ends were mapped relative to $A+G$ sequencing ladders of each probe, although only that for construct 3 is shown. The $3^{\prime}$ ends map to the 15-base region upstream of the TATA box in constructs 2 and 3 just as they do in the intact c-myc gene, although the exact pattern of 3 ' ends within this region differs slightly from the intact gene. Inversion of the c-myc element (construct 4) resulted in termination of transcription in the 4-base region immediately upstream of the inverted TATA motif. Thus, in both orientations, termination occurred upstream of the TATA element. Similar observations were made when the 28 - 
Roberts et al.

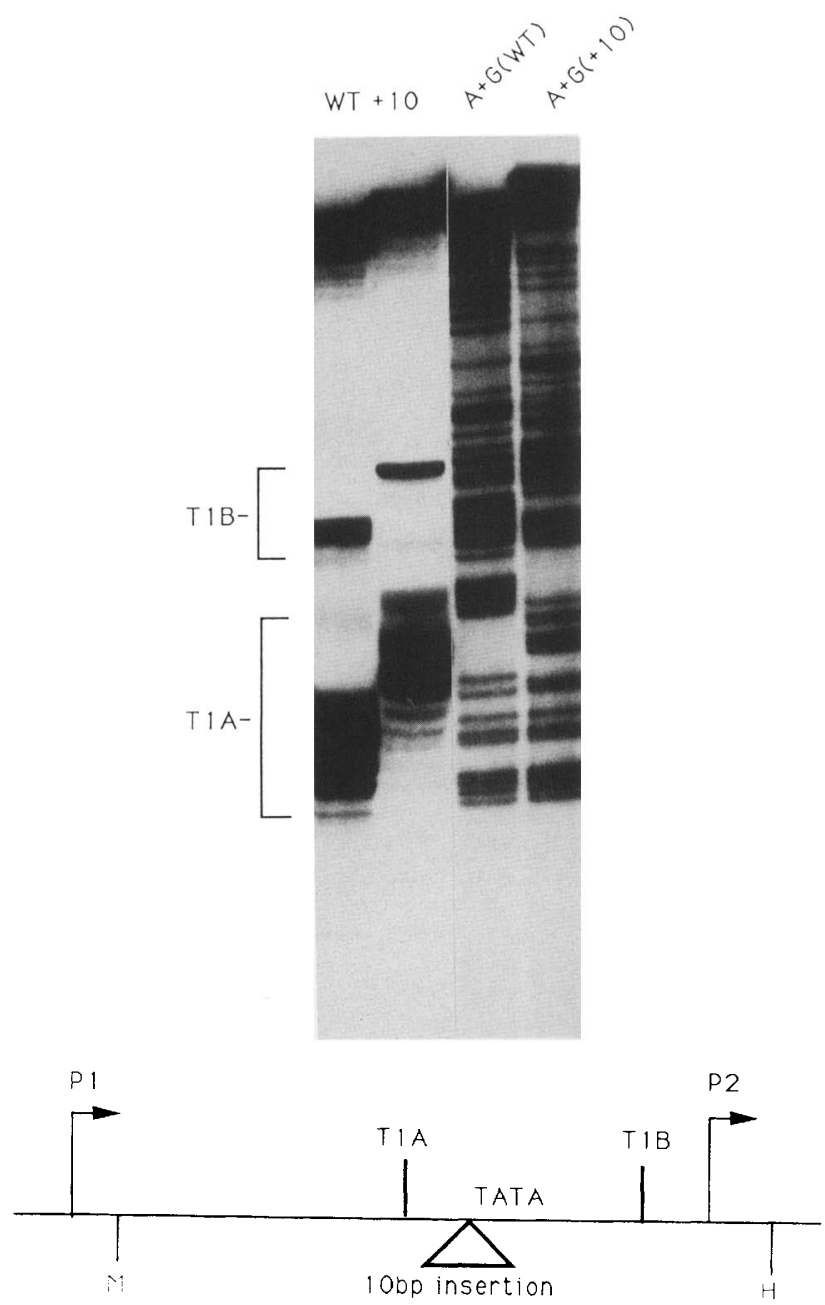

Figure 5. Termination at T1A shifts in response to an insertion upstream of the P2 TATA box. Transcripts of pSX943 (WT) and the 10-base insertion mutant $\mathrm{pSX} 943 /+10$ from injected oocytes were analyzed by exonuclease VII protection with their respective $M s p \mathrm{I}-\mathrm{HhaI}$ probes $3^{\prime}$-end-labeled at $M s p \mathrm{I}$. A + G sequencing ladders of the two probes are shown. The diagram shows the position of the 10-base insertion and the MspI (M) and the HhaI $(\mathrm{H})$ sites.

base c-myc element was inserted into the adenovirus major late transcription unit (data not shown). The level of termination in these chimeric constructs was significantly lower than it was in the context of the complete c-myc gene, suggesting that sequences outside the 28base element contribute to the efficiency of termination. In summary, a 28-base sequence, including T1A and sequences downstream, behaves as an autonomous though quite inefficient terminator of pol II transcription in the oocyte.

\section{A factor with DNA-binding specificity} that correlates with termination

Because the sequence overlapping the TATA box is necessary for termination by pol II, we looked for candidate termination factors that bind to this site. For this purpose, gel mobility-shift assays were conducted with the 28 -bp sequence $(-20$ to -47 ; Fig. 2$)$ of the mouse c-myc gene as a probe, which can cause termination (Fig. 7). DNA-binding activity was assayed in a Xenopus oocyte nuclear extract and a HeLa whole-cell extract (WCE) in Figure 8, A and $\mathrm{B}$, respectively. The major complexes detected in both extracts had similar mobilities (Fig. 8B) and sequence specificities. Sequence specificities were assessed by competition with excess unlabeled 28-mers corresponding to the sequences whose termination properties were determined in Figure 4. The results in Figure $8 \mathrm{~A}$ show that all four mutant oligonucleotides competed for the oocyte-binding factor significantly less well than the wild-type sequence. The TATT mutation competed slightly more effectively than the other three mutants. Similarly, the Bgl(TATA) and TATA-Nco mutant oligonucleotides competed less efficiently for the HeLa factor than the wild-type sequence (Fig. 8B). In summary, we detected related DNA-binding activities in Xenopus oocytes and HeLa cells that bind an element of the mouse c-myc gene that functions as a transcription terminator. The DNA-binding affinity of these factors to wild-type and mutant sequences closely correlated with their terminator function.

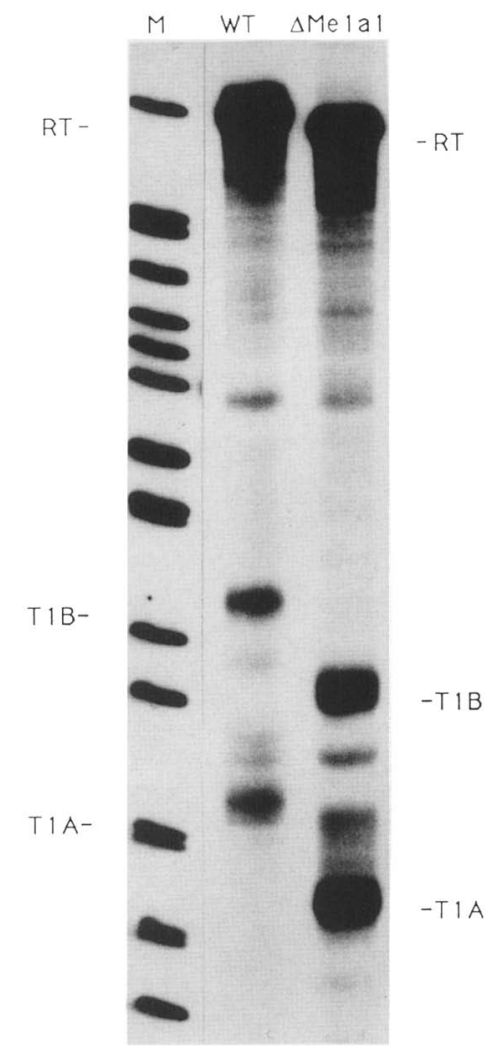

Figure 6. Deletion of the upstream GA-rich element does not affect termination at $\mathrm{T} 1$. S1 protection of RNA from oocytes injected with pSX943 (WT) or pSX943/ MMElal, which has a 14-base deletion. The probes were 325- and 311-base PvuII-NotI fragments 3 '-end-labeled at $P$ vulI (see Fig. 1A) made from the respective templates. 


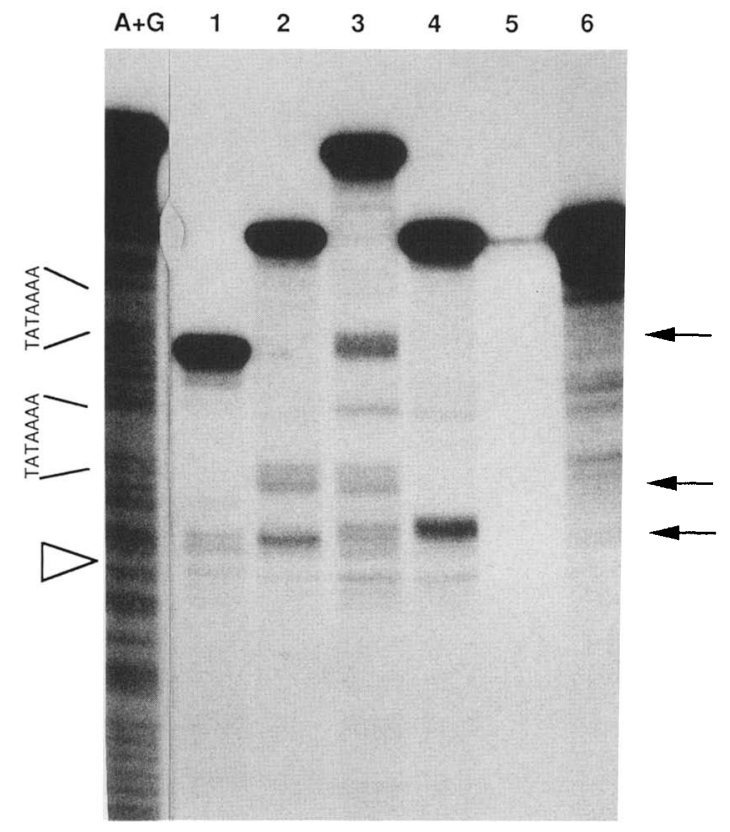

$\alpha$-globin

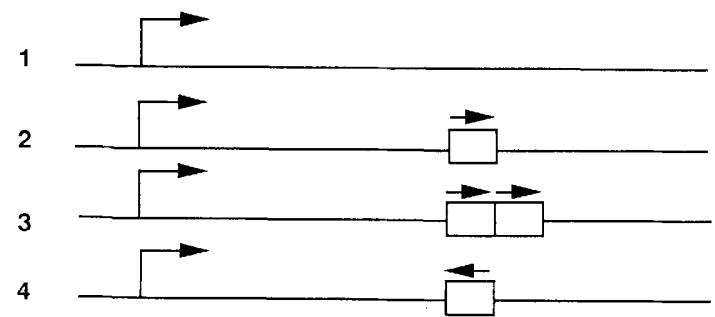

Figure 7. A 28-base c-myc element induces a low level of termination in the $\alpha_{1}$-globin gene. Sl protection of RNA from oocytes injected with plasmids pSP64 $\alpha$-globin, p $\alpha \mathrm{T} 1 \mathrm{~A}-28 \mathrm{~S}$, p $\alpha$ T1A-28SS, and p $\alpha$ T1A-28A is shown in lanes 1-4, respectively. The probes were single-stranded, $3^{\prime}$-end-labeled TaqI fragments that span the HindII site where the 28-base mouse T1A element was inserted (see Materials and methods). An $\mathrm{A}+\mathrm{G}$ sequencing ladder of the -28SS probe is shown, with the positions of the two c-myc TATA boxes marked and the $5^{\prime}$ position of insertion of the most $5^{\prime}$ element denoted by the arrowhead. In lane 5 , the $-28 \mathrm{~S}$ probe was hybridized to RNA from uninjected oocytes as a negative control. In lane 6, the $-28 \mathrm{~S}$ probe was hybridized to SP6 RNA transcribed from p $\alpha$ T1A-28S, together with uninjected oocyte RNA as a control for artifactual $\mathrm{S} 1$ cleavage. The arrows (right) mark termination sites within the c-myc sequences. (Diagram) Plasmids used in lanes 1-4, respectively.

T1A termination occurs at homologous positions in the mouse and human c-myc genes, although the sequences outside the TATA box are not very highly conserved between the two genes in this region (see Fig. 2). Only 3 of the 6 bases downstream of the TATA box are conserved, and there is a 3 -base insertion in the mouse gene relative to the human upstream of the TATA box at the termination site itself. If a DNA-binding factor is responsible for termination at $\mathrm{T} 1 \mathrm{~A}$, then the divergent human and mouse sequences should both bind the same factor. We looked for a factor in oocyte and HeLa extracts that binds the human T1A sequence and tested whether it also bound the mouse sequence in a competition assay. A gel mobility-retardation assay with a radiolabeled 29-mer oligonucleotide of the human T1A sequence is shown in Figure 9. In this experiment the oocyte nuclear extract was compared with a chromatographic fraction of a HeLa nuclear extract. The result shows that DNAbinding factors with identical mobilities in both oocyte and HeLa nuclear extracts bind to both the human and mouse sequences. More importantly, the wild-type mouse sequence competed efficiently for the factor binding to the human terminator element in both extracts (Fig. 9, lanes 5,6,13,14). The TATA-Nco mutation of the mouse sequence competed less well than wild type (lanes $7,8,15,16)$. The 28-mer mouse-binding site used in these studies consistently showed a higher affinity for the putative termination factor than the human sequence.

Because the binding site of this factor overlaps the TATA box, it was necessary to test the possibility that it was the basal transcription factor TBP, which is a component of TFIID. The oocyte factor was compared with in vitro-translated human TBP in a gel mobility-shift assay by use of the same 28 -mer probe under conditions optimized for TFIID binding (Fig. 8C). The complex with the oocyte factor had a significantly higher mobility than the TBP complex, as well as altered sequence specificity. The TATA-Nco mutant oligonucleotide competed for TBP about as efficiently as the wild-type sequence, whereas the $B g l(T A T A)$ mutant competed poorly. This observation contrasts with the results in Figure 8, A and $\mathrm{B}$, which show that the TATA-Nco mutant competes poorly for the oocyte and HeLa factors implicated in termination. In conclusion, it is most likely that the higher mobility complex that correlates with termination is distinct from TBP. We refer to this DNA-binding activity as TBF I for terminator-binding factor.

\section{Discussion}

We have identified two sites of termination, T1A and $\mathrm{T} 1 \mathrm{~B}$, for transcription from the $\mathrm{P} 1$ promoter of the c-myc gene. These sites occur in the region between 5 and 45 bases upstream of the initiation site for the P2 promoter. $\mathrm{T} 1 \mathrm{~B}$ corresponds to a $\mathrm{T}$-rich sequence that superficially resembles the $\mathrm{T} 2$ site (Fig. 1A), where P2 transcripts are attenuated. T1A has an unrelated sequence and functions independently of T1B. Termination of P1 transcripts has also been reported recently by Wright et al. (1991). A previous report of termination of P1 RNA at T2 in the human c-myc gene was incorrect (Bentley and Groudine 1988), probably because of poor resolution of the size-fractionated material used for mapping. We do not know the function of termination at $\mathrm{T} 1$, but it is possible that it regulates $P 1$ transcription. Because the T2 site specifically regulates $\mathrm{P} 2$ transcription /Spencer et al. 1990; Roberts and Bentley 1992), it was thought previously that P1 RNA was not subject to control by attenuation. The idea that the $c-m y c$ gene escapes normal 
A

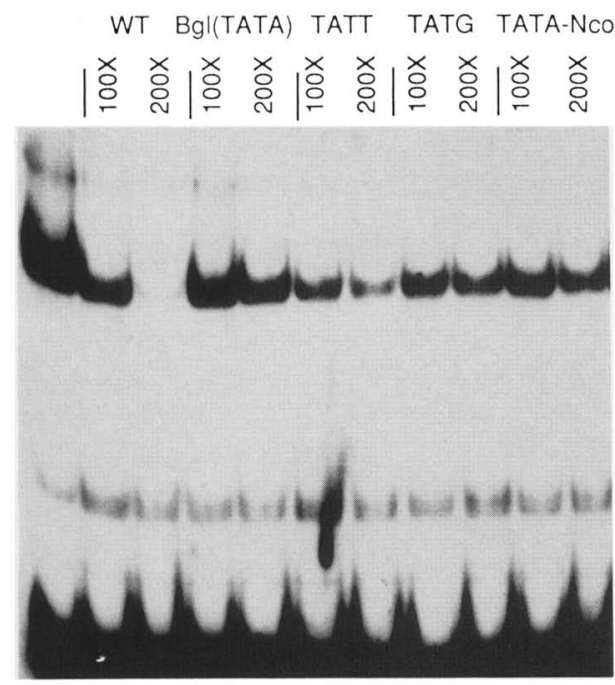

B

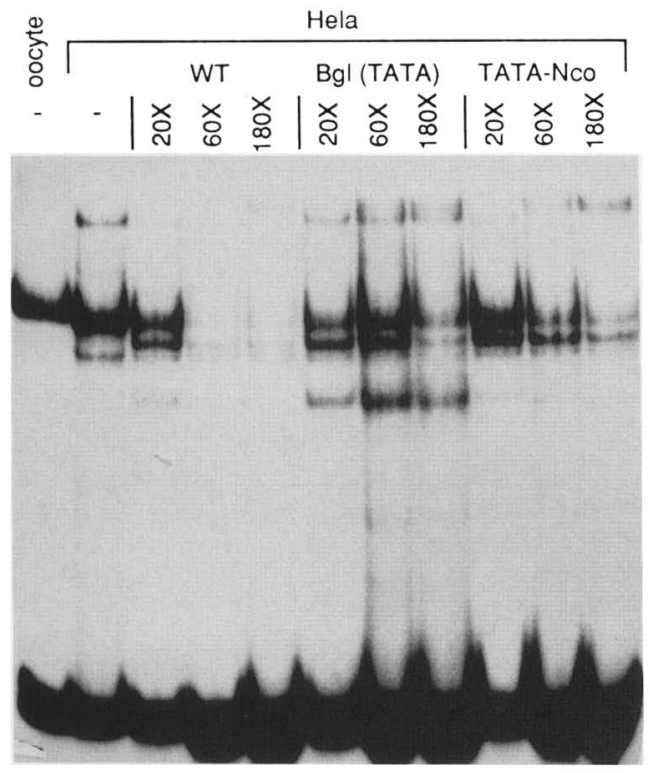

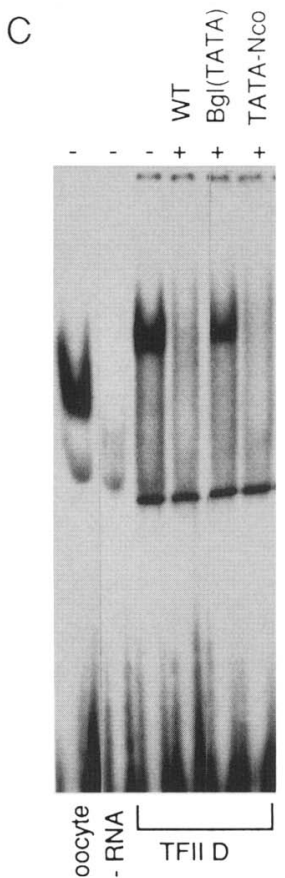

Figure 8. A DNA-binding factor with specificity that correlates with termination. (A) Gel retardation of a 28 -bp probe, including the mouse c-myc TlA site with Xenopus oocyte nuclear extract. Wild-type (WT) and mutant oligonucleotide competitors, as well as the molar excess used, are marked. Poly[d/GC) - [G-C)] was at $5 \mu \mathrm{g} / \mathrm{ml}$. (B) Gel retardation with HeLa WCE as in $A$, except that poly[d(G-C) $\cdot(\mathrm{G}-\mathrm{C})]$ was at $25 \mu \mathrm{g} / \mathrm{ml}$. The first lane contains the Xenopus oocyte complex. (C) Gel retardation of the mouse T1A 28-mer with the in vitro-translated human TBP component of TFIID. The first lane shows the oocyte complex. Lanes are marked $+/$ - competitors, which were used at a 500-fold molar excess. (-RNA) Control reticulocyte lysate. Poly $[\mathrm{d}(\mathrm{G}-\mathrm{C}) \cdot(\mathrm{G}-\mathrm{C})]$ competitor at $10 \mu \mathrm{g} / \mathrm{ml}$ and reticulocyte lysate at $4 \mu \mathrm{l}$ per reaction were used. attenuation controls in Burkitt's lymphoma and rat immunocytoma (Bentley and Groudine 1986b; Cesarman et al. 1987; Axelson et al. 1991) by a promoter switch from P2 to P1 (Spencer et al. 1990) may need to be re-examined in light of the potential P1 attenuation sites identified here. In summary, the identification of $\mathrm{T} 1$ raises the possibility that transcription from both $\mathrm{c}-m y c$ promoters is regulated by attenuation at independent positions in the gene.

The mechanism of termination at TlA was investigated in detail. The fact that relatively large insertions and deletions near T1A (Figs. 5 and 6) did not affect the efficiency of termination implies that polymerase arrest does not have a stringent RNA secondary structure requirement in agreement with previous studies of pol II termination conducted in vitro (Dedrick et al. 1987). Termination at T1A occurs at a relatively constant distance upstream of a sequence element that overlaps the TATA box and 6 bases of $3^{\prime}$-flanking sequence. A 28-base sequence that includes this element was sufficient to program accurate but inefficient termination when it was inserted downstream of the $\alpha 1$-globin or adenovirus MLP (Fig. 7 and data not shown). A factor, TBF I, which binds to this element in a manner that closely correlates with termination at T1A, has been identified in nuclear extracts of Xenopus oocytes and HeLa cells (Figs. 8 and 9). Each of the four mutations that inhibited termination at $\mathrm{T} 1 \mathrm{~A}$ in the oocyte resulted in reduced affinity for the factor present in oocyte nuclei.

Although its binding site overlaps the TATA box, TBF 


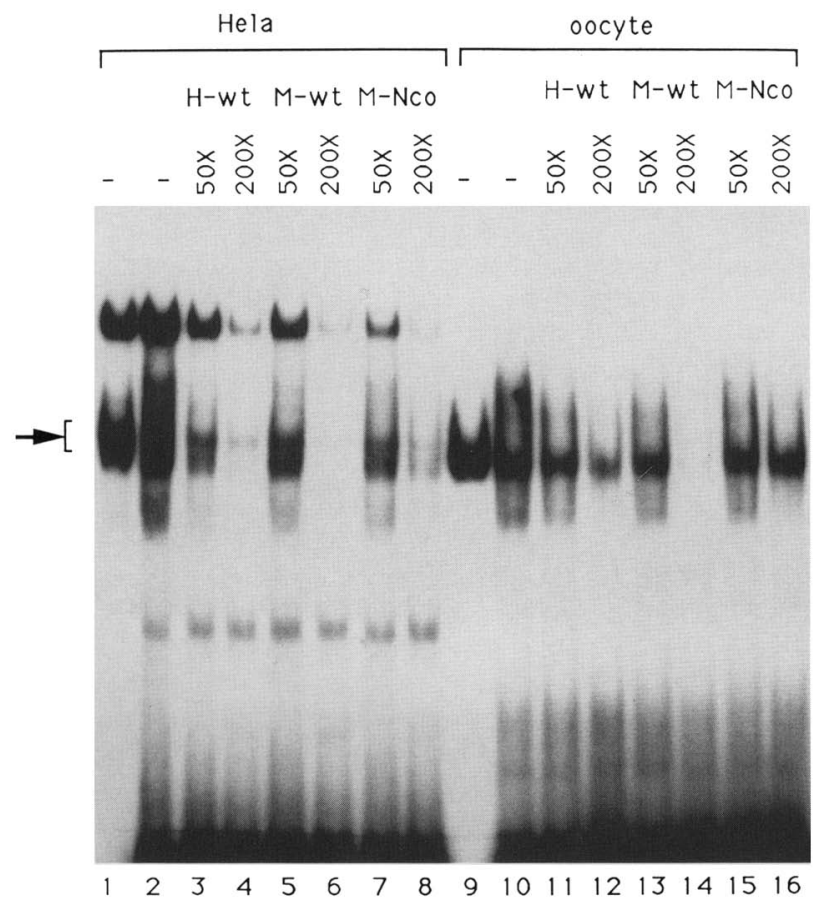

Figure 9. The divergent mouse and human TlA sequences bind the same factor in HeLa and Xenopus oocyte nuclear extracts. Binding reactions with fractionated HeLa nuclear extract or oocyte nuclear extract were with $25 \mu \mathrm{g} / \mathrm{ml}$ of poly[d/GC) $\cdot\left(\mathrm{C}_{\mathrm{r}}\right.$-C)]. The mouse TIA 28 -mer ${ }^{32}$ P-labeled probe (lanes 1,9) was compared with the human T1A 29-mer (lanes 2-8,10-16). Competitors were the human and mouse wild-type oligonucleotides (H-wt and $\mathrm{M}-\mathrm{wt}$, respectively), and the mouse TATANco oligonucleotide (M-Nco). (Arrow) The TBFI complex.

I is distinct from the TBP component of TFIID by the following criteria: Disruption of its binding site does not necessarily inhibit P2 promoter function (Fig. 4), and its sequence specificity and mobility in a gel retardation assay differ from in vitro-translated TBP (Fig. 8). There are several precedents for DNA-binding proteins that compete in vitro with TFIID for various binding sites, including TARP (Mitchell and Benfield 1990), LBP-1 (Kato et al. 1991), engrailed (Okhuma et al. 1990), and P1 transposase (Kaufman and Rio 1991). It is possible that under some conditions TBF I might also compete with TFIID; however, we have no evidence to support this possibility. The TATA-Nco mutation, which is a poor binding site for TBF I, does not have increased P2 promoter activity in the oocyte. The consequences of TBF I binding for $\mathrm{P} 2$ promoter function are unknown, but there may be an interplay between termination at T1A and initiation at P2. It would be interesting to know whether P1 transcription can interfere with the $\mathrm{P} 2$ promoter under some conditions and whether TBF I could prevent such interference. We have not observed promoter interference; however, our transcription assays are not efficient enough for both promoters to be simultaneously active on the same template.

A DNA-binding factor has been implicated previously in pol II termination in the adenovirus MLP. In this case, an inverted CCAAT box functioned as an orientationspecific termination element /Connelly and Manley 1989a). The sequence specificity of termination correlated with DNA binding by the CP1 factor (Connelly and Manley 1989b). Other promoter and enhancer elements tested by these investigators failed to induce termination. The inverted CCAAT terminator is completely orientation specific, unlike the TBF I terminator.

T1A resembles pol I terminators in that it entails a protein-binding site situated 10-20 bases downstream of where polymerases are released (Grummt et al. 1986; McStay and Reeder 1990), although the element is orientation specific in the latter case. The termination signal at TlA contrasts with the T-rich terminator at the end of the first exon of the human c-myc gene, where the sequences necessary for termination are located entirely upstream of the site of polymerase release (Bentley and Groudine 1988). Further studies are required to determine the function of the $\mathrm{T} 1$ termination site. Moreover, purification of TBF I will enable us to test directly whether it causes termination in an in vitro transcription system.

\section{Materials and methods \\ Oocyte injection and RNA mapping}

Injection of centrifuged oocytes and RNA extraction were performed as described (Bentley et al. 1989). DNA (1.5 ng) was injected into each oocyte and incubated overnight at room temperature. Under these conditions, all transcription is by pol II. S1 protection was generally carried out on one oocyte equivalent of RNA as described (Bentley and Groudine 1988), except that $\mathrm{S} 1$ nuclease was used at $250 \mathrm{U} / \mathrm{ml}$. Digestion was done at room temperature for $30 \mathrm{~min}$. Exonuclease VII protection 16 $\mathrm{U} / \mathrm{ml}$ ) was carried out at $37^{\circ} \mathrm{C}$ for $1 \mathrm{hr}$ in a $200-\mu \mathrm{l}$ reaction containing $20 \mathrm{~mm}$ Tris (pH 8.0), $25 \mathrm{~mm} \mathrm{NaCl}$, and $10 \mathrm{~mm}$ EDTA. Reactions were terminated by ethanol precipitation and electrophoresed on $5 \%$ denaturing polyacrylamide gels.

\section{Plasmids and probes for RNA mapping}

pSX943 contains the 943-base SmaI-XhoI fragment of mouse c-myc exon 1, which extends from 425 bases upstream of the P1 start site to 360 bases downstream of the P2 start site cloned into the SmaI-SalI site of the Bluescribe derivative pVZ (Henikoff and Eghtedarzadeh 1987).

pPX490 contains the 490-base PvuII-Xhol fragment of mouse c-myc exon 1, which starts 24 bases downstream of the P1 start site (see Fig. 1A) inserted into the SmaI-SalI site of pVZ.

M13 SX943 contains the SmaI-Xhol fragment of pSX943 in mp18. Single-stranded 5 '-end-labeled probes for mapping the P1 and P2 $5^{\prime}$ ends (Fig. 4B) were synthesized by primed extension on this template followed by restriction cutting. The $272-$ base Pl probe was primed with the oligonucleotide 5'-CTGCCCTTCAGGAGGCAGGA-3' 75 bases downstream of the start site and cut with RsaI. The 160 -base $\mathrm{P} 2$ probe was primed with oligonucleotide 5'-CTCTCACTCCAGAGCTGCCT-3' 113 bases downstream of the start site and cut with BamHI.

The following plasmids were derived from the wild-type parent plasmid pSX 943 by mismatched oligonucleotide-directed mutagenesis (Nakamaye and Eckstein 1986): In pSX943/ $\triangle$ MElal (Fig. 6), the 14-base sequence 5'-AGAAGGGAGGG- 
GAG-3' (see Fig. 2) was deleted. In pSX943/Bg1(TATA) (Figs. 3 and 4), the sequence TATAAA of the P2 promoter was replaced with AGATCT. In pSX943/TATA-Nco (Fig. 4), the sequence GAAGCT adjacent to the TATA box was replaced with CCATGG. In pSX943/+10 (Fig. 5), the sequence TCAGATCTGC was inserted immediately upstream of the first $T$ of the P2 TATA box.

The HindIII site in the polylinker of pSX943 was removed by partial digestion, filling in with Klenow fragment, and ligation to make plasmid pSX $943 / \Delta \mathrm{H} 3$, which has unique $B a m H I$ and HindIII sites at positions -44 and -20 (Fig. 2).

The plasmids pSX943/TATT and pSX943/TATG were made by replacing the 24-base BamHI-HindIII fragment of pSX $943 \Delta \mathrm{H} 3$ with the corresponding single point mutations in the fourth position of the TATA consensus.

pGC1HR and pmycsTATA (Fig. 3B) (Bentley et al. 1989) contain the wild-type human c-myc gene and a 7-base deletion of the P2 TATA box, respectively.

pSP64 $\alpha$-globin (Fig. 7) is a derivative of pSP64 containing the human $\alpha$-globin gene from -118 to +913 . $\alpha \alpha$ TlA-28S, p $\alpha$ T1A-28A, and p $\alpha$ T1A-28SS (Fig. 7) are derived from pSP64 $\alpha$ globin by insertion of a 28-base double-stranded oligonucleotide, GATCCTGAGTCGCAGTATAAAAGAAGCT, into the HindII site in exon 2 in the sense (S) or antisense (A) orientation. The p $\alpha$ T1A-28SS construct contains two copies in the sense orientation.

The 3 '-end-labeled TaqI fragments derived from these plasmids were strand-separated by hybridization with single-

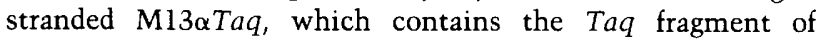
p $\alpha$ TlA-28S cloned in the antisense orientation into the AccI site of M13 mpl8.

paT1A-120 (Fig. 3A) was derived from pSP64 $\alpha$-globin into which a PvuII-HindIII fragment of the mouse c-myc P2 promoter extending from -140 to -20 was inserted by blunt-end ligation into the NCoI site at position +35 of the globin gene. p $\alpha$ T1A-120Bgl(TATA) was made by the same method, except that the PvuII-HindIII fragment was from the mutant pSX943/ Bgl(TATA) (above).

p $\alpha$ PX490 (Fig. 1E) contains the $\alpha 1$-globin promoter in place of the c-myc Pl promoter. A fragment of the globin gene from -118 to +35 was inserted upstream of the mouse c-myc 490base PvuII-XhoI exon 1 fragment (see Fig. $1 \mathrm{~A}$ ) in the $\mathrm{pVZ}$ vector.

\section{In vitro transcription}

Reactions were carried out at $30^{\circ} \mathrm{C}$, for $45 \mathrm{~min}$ in $20 \mu \mathrm{l}$ containing $140 \mu \mathrm{g}$ of HeLa nuclear extract $(20 \mathrm{mg} / \mathrm{ml})$ made by the method of Shapiro et al. (1988), supplemented with $1 \mu l$ of in vitro-translated human TBP (Kao et al. 1990). The reactions contained a final concentration of $7 \mathrm{mM}$ HEPES $(\mathrm{pH} 7.9$ ), $7 \%$ glycerol, $75 \mathrm{mM} \mathrm{KCl}, 0.07 \mathrm{~mm}$ EDTA and EGTA, $0.7 \mathrm{~mm}$ dithiothreitol, $3.6 \mathrm{~mm} \mathrm{MgCl}_{2}, 2.85 \%$ polyvinyl alcohol, $2.5 \mathrm{~mm}$ creatine phosphate, $0.5 \mathrm{~mm}$ NTPs, and $0.5 \mu \mathrm{g}$ of supercoiled DNA. The reactions were terminated by digestion with 7.5 units of DNase for $15 \mathrm{~min}$ at $37^{\circ} \mathrm{C}$, digested with proteinase $\mathrm{K}$, and phenol/chloroform extracted. RNA was then ethanol precipitated.

\section{Cell extracts and gel retardation}

Oocyte nuclei were isolated by dissection under mineral oil (Lund and Dahlberg 1989). Nuclei were extracted on ice in digitonin lysis buffer (G. Evan, pers. comm.) containing $200 \mathrm{~mm}$ $\mathrm{NaCl}, 25 \mathrm{~mm}$ Tris- $\mathrm{HCl}$ (pH 8.0), $1 \mathrm{~mm}$ EDTA, 0.1\% digitonin, $0.1 \mathrm{mM}$ DTT, $0.3 \mathrm{mM}$ PMSF, $2 \mu \mathrm{M}$ leupeptin, $1 \mathrm{~mm}$ benzamidine, $10 \mu \mathrm{M} \mathrm{E} 64,5 \mathrm{~mm} \mathrm{NaF}$, and $1 \mathrm{mM} \mathrm{Na}_{3} \mathrm{VO}_{4}$. After brief centrifu- gation, the supernatant was quick-frozen in liquid nitrogen and stored at $-70^{\circ} \mathrm{C}$ in the lysis buffer.

HeLa WCE was made as follows: Cells were washed twice in cold PBS and lysed at a concentration of $3 \times 10^{7}$ cells $/ \mathrm{ml}$ in digitonin lysis buffer without the phosphatase inhibitors or E64 containing additional $0.5 \mu \mathrm{M}$ soybean trypsin inhibitor and 0.15 $\mu \mathrm{M}$ aprotinin. After a 10 -min incubation on ice, the sample was homogenized by pipetting, transferred to a microcentrifuge tube, and centrifuged for $5 \mathrm{~min}$ at $4^{\circ} \mathrm{C}$. The supernatant 16 $\mathrm{mg} / \mathrm{ml}$ ) was aliquoted, frozen in liquid nitrogen, and stored at $-70^{\circ} \mathrm{C}$ until use. HeLa nuclear extract (Shapiro et al. 1988) was fractionated on Bio-Rex 70, and the $0.1 \mathrm{M} \mathrm{KCl}$ flowthrough fraction $(20 \mathrm{mg} / \mathrm{ml})$ was used in Figure 9.

For gel retardation, double-stranded oligonucleotides with 4-base overhangs were labeled by filling in with Klenow fragment or Sequenase by using $\left[\alpha^{-32} \mathrm{P}\right] \mathrm{dCTP}$ to a sp. act. of $6 \times 10^{6}$ $\mathrm{cpm} / \mathrm{pmole}$. The two annealed oligonucleotides for the mouse sequence used in Figure 8 were 5'-GATCCTGAGTCGCAGTATAAAAGA- $3^{\prime}$ and $5^{\prime}$-AGCTTCTTTTATACTGCGACTCAG-3'. For the human sequence used in Figure 9, they were GATCGCGCTGAGTATAAAAGCCGGT and GATCACCGGCTTTATACTCAGCGC. Mutant competitors were homologous pairs of oligonucleotides with 4-base overhangs, which were not filled in. The sequences of these competitors were $B g l$ (TATA), GATCCTGAGTCGCAGAGATCTAGAAGCT; TATT/TATG, GATCCTGAGTCGCAGTAT/T/G)AAAGAAGCT; and TATA-NCO, GATCCTGAGTCGCAGTATAAAACCATGG. Extract from 1.5-2 oocyte nuclei $(\sim 5 \mu \mathrm{g}), 16 \mu \mathrm{g}$ of HeLa WCE, or $10 \mu \mathrm{g}$ of fractionated HeLa nuclear extract was incubated for $5 \mathrm{~min}$ on ice with $5-25 \mu \mathrm{g} / \mathrm{ml}$ of poly[d(G-C) $\cdot(\mathrm{G}-$ C)] (Pharmacia) as nonspecific competitor, in $100 \mathrm{mM} \mathrm{NaCl}, 10$ mM Tris ( $\mathrm{pH} 7.5), 1 \mathrm{~mm}$ EDTA, $1 \mathrm{~mm}$ benzamidine, $1 \mathrm{~mm}$ DTT, and $5 \%$ glycerol. Specific competitor was added in a $10-\mathrm{min}$ incubation, followed by the addition of $50,000 \mathrm{cpm}$ of probe, in a total volume of $20 \mu \mathrm{l}$, for an additional $20 \mathrm{~min}$ on ice. Reactions were loaded on $4 \%$ native polyacrylamide gels and run at $4^{\circ} \mathrm{C}$ in $0.5 \times \mathrm{TBE}$ buffer $(45 \mathrm{~mm}$ Tris, $45 \mathrm{~mm}$ boric acid, $1 \mathrm{~mm}$ EDTA at $\mathrm{pH} 8.0$.

Human TBP was transcribed and translated in vitro from plasmid pKB104 as described (Kao et al. 1990). In Figure $8 \mathrm{C}$ the buffer used for the oocyte and TFID-binding reactions was 12 $\mathrm{mM}$ Tris- $\mathrm{HCl}, 40 \mathrm{~mm}$ HEPES, $60 \mathrm{mM} \mathrm{KCl}, 12 \%$ glycerol, and 8 $\mathrm{mM} \mathrm{MgCl}$ (Horikoshi et al. 1989). Gel electrophoresis was as described above.

\section{Acknowledgments}

We thank R. Treisman, H. Land, and V. Bardwell for helpful suggestions. We are indebted to the Imperial Cancer Research Fund animal unit, Clare Hall for supplying Xenopus oocytes, and A. Beckett for help in preparing the manuscript.

The publication costs of this article were defrayed in part by payment of page charges. This article must therefore be hereby marked "advertisement" in accordance with 18 USC section 1734 solely to indicate this fact.

\section{References}

Adhya, J. and M. Gottesman. 1982. Promoter occlusion: Transcription through a promoter may inhibit its activity. Cell 29: 939-944.

Ashfield, R., P. Enriquez-Harris, and N. Proudfoot. 1991. Transcriptional termination between closely linked human complement genes $\mathrm{C} 2$ and factor $\mathrm{B}$ : Common termination factor for C2 and c-myc. EMBO I. 10: 4197-4207.

Asselin, C., A. Nepveu, and K. Marcu. 1989. Molecular require- 
ments for transcriptional initiation of the murine c-myc gene. Oncogene 4: 549-558.

Axelson, H., W. Pear, C. Panda, H. Bazin, G. Klein, and J. Sumegi. 1991. Transcriptional deregulation of myc in IgH/ myc $6 ; 7$ translocation carrying rat immunocytomas. Genes, Chromosomes, Cancer 3: 142-148.

Bartsch, I., C. Shoneberg, and I. Grummt. 1988. Purification and characterization of TTF1, a factor that mediates termination of mouse ribosomal DNA transcription. Mol. Cell. Biol. 8: 3891-3897.

Bateman, E. and M. Paule. 1988. Promoter occlusion during ribosomal RNA transcription. Cell 54: 985-992.

Bentley, D.L. and M. Groudine. 1986a. A block to elongation is largely responsible for decreased transcription of $\mathrm{c}-\mathrm{myc}$ in differentiated HL60 cells. Nature 321: 702-706.

- 1986b. Novel promoter upstream of the human c-myc gene and regulation of $\mathrm{c}-\mathrm{myc}$ expression in B-cell lymphomas. Mol. Cell. Biol. 6: 3481-3489.

- 1988. Sequence requirements for premature termination of transcription in the human c-myc gene. Cell 53: 245-256.

Bentley, D.L., W.L. Brown, and M. Groudine. 1989. Accurate, TATA box-dependent polymerase III transcription from promoters of the c-myc gene in injected Xenopus oocytes. Genes \& Dev. 3: 1179-1189.

Cesarman, E., R. Dalla-Favera, D. Bentley, and M. Groudine. 1987. Mutations in the first exon are associated with altered transcription of $\mathrm{c}-\mathrm{myc}$ in Burkitt lymphoma. Science 238: 1272-1275.

Chodchoy, N., N. Pandey, and W. Marzluff. 1991. An intact histone 3 '-processing site is required for transcription termination in a mouse histone H2A gene. Mol. Cell. Biol. 11: 497-509.

Citron, B., E. Falck-Pederson, M. Salditt-Georgieff, and J. Darnell. 1984. Transcription termination occurs within a 1000 base pair region downstream from the poly(A) site of the mouse $\beta$-globin (major) gene. Nucleic Acids Res. 12: 87238731 .

Connelly, S. and J. Manley. 1988. A functional mRNA polyadenylation signal is required for transcription termination by RNA polymerase II. Genes \& Dev. 2: 440-452.

- 1989a. A CCAAT box sequence in the Adenovirus major late promoter functions as part of an RNA polymerase II termination signal. Cell 57: 561-571.

- $1989 \mathrm{~b}$. RNA polymerase II transcription termination is mediated specifically by protein binding to a CCAAT box sequence. Mol. Cell. Biol. 9: 5254-5259.

Corbin, V. and T. Maniatis. 1989. Role of transcriptional interference in the Drosophila melanogaster Adh promoter switch. Nature 337: 279-282.

Cullen, B.R., P.T. Lomedico, and G. Tu. 1984. Transcriptional interference in avian retroviruses-Implications for the promoter insertion model of leukaemogesis. Nature 307: 241245.

Dedrick, R.L., C.M. Kane, and M.J. Chamberlin. 1987. Purified RNA polymerase II recognizes specific termination sites during transcription in vitro. J. Biol. Chem. 262: 9098-9108.

Eick, D. and G. Bornkamm. 1986. Transcriptional arrest within the first exon is a fast control mechanism in c-myc gene expression. Nucleic Acids Res. 14: 8331-8346.

Grummt, I., H. Rosenbauer, I. Niedermeyer, U. Meier, and A. Ohrlein. 1986. A repeated $18 \mathrm{bp}$ sequence motif in the mouse rDNA spacer mediates binding of a nuclear factor and transcription termination. Cell 45: 837-846.

Hall, D. 1990. Regulation of c-myc transcription in vitro: Dependence on the guanine-rich promoter element MElal. Oncogene 5: 47-54.
Henderson, S., K. Ryan, and B. Sollner-Webb. 1989. The promoter proximal rDNA terminator augments initiation by preventing disruption of the stable transcription complex caused by polymerase read-in. Genes \& Dev. 3: 212-223.

Henikoff, S. and M. Eghtedarzadeh. 1987. Conserved arrangement of nested genes at the Drosophila Gart locus. Genetics 117: 711-725.

Hernandez, N. 1985. Formation of the $3^{\prime}$ end of Ul snRNA is directed by a conserved sequence located downstream of the coding region. EMBO I. 4: 1827-1837.

Hess, J., M. Parisi, J. Bennett, and D. Clayton. 1991. Impairment of mitochondrial transcription termination by a point mutation associated with the MELAS subgroup of mitochondrial encephalomyopathies. Nature 351: 236-239.

Horikoshi, M., C.K. Wang, H. Fujii, T.A. Cromlish, P.A. Weil, and R.G. Roeder. 1989. Purification of a yeast TATA boxbinding protein that exhibits human transcription factor IID activity. Proc. Natl. Acad. Sci. 86: 4843-4847.

Kao, C., P. Lieberman, M. Schmidt, Q. Zhon, R. Pei, and A. Berk. 1990. Cloning of a transcriptionally active human TATA binding factor. Science 248: 1646-1650.

Kato, H., M. Horikoshi, and R. Roeder. 1991. Repression of HIV-1 transcription by a cellular protein. Science 251: 14761479.

Kaufman, P. and D. Rio. 1991. Drosophila P-element transposase is a transcriptional repressor in vitro. Proc. Natl. Acad. Sci. 88: 2613-2617.

Kerppola, T. and C. Kane. 1990. Analysis of the signals for transcription termination by purified RNA polymerase II. Biochemistry 29: 269-278.

Labhart, P. and R. Reeder. 1986. Characterization of three sites for RNA 3' end formation in the Xenopus ribosomal gene spacer. Cell 45: 431-443.

Logan, J., E. Falck-Pederson, J.E. Darnell, and T. Shenk. 1987. A poly(A) addition site and downstream terminator region are required for efficient cessation of transcription by RNA polymerase II in the mouse $\beta^{\text {mai }}$ globin gene. Proc. Natl. Acad. Sci. 84: 8306-8310.

Lund, E. and J. Dahlberg. 1989. In vitro synthesis of vertebrate Ul snRNA. EMBO I. 8: 287-292.

McGeady, M., T. Wood, J. Maizel, and G. Van de Woude. 1986. Sequences upstream from the mouse c-mos oncogene may function as a transcription termination signal. DNA 5: 289298.

McStay, B. and R. Reeder. 1990. A DNA-binding protein is required for termination of transcription by RNA polymerase I in Xenopus laevis. Mol. Cell. Biol. 10: 2793-2800.

Miller, H., C. Asselin, D. Dufort, T. Yang, K. Gupta, K.B. Marcu, and A. Nepveu. 1989. A cis-acting element in the promoter region of the murine c-myc gene is necessary for transcriptional block. Mol. Cell. Biol. 9: 5340-5349.

Mitchell, M. and P. Benfield. 1990. Two different RNA polymerase II initiation complexes can assemble on the rat brain creatine kinase promoter. J. Biol. Chem. 265: 8259-8267.

Nakamaye, K. and F. Eckstein. 1986. Inhibition of restriction endonuclease Ncil by phosphorothioate groups and its application to oligonucleotide-directed mutagenesis. Nucleic Acids Res. 14: 9679-9688.

Nepveu, A. and K. Marcu. 1986. Intragenic pausing and antisense transcription within the murine c-myc locus. $E M B O F$. 5: 2859-2865.

Ohkuma, Y., M. Horikoshi, R. Roeder, and C. Desplan. 1990. Engrailed, a homeodomain protein, can repress in vitro transcription by competition with the TATA box-binding protein transcription factor TFIID. Proc. Natl. Acad. Sci. 87: 2289-2293. 


\section{Roberts et al.}

Proudfoot, N.J. 1986. Transcriptional interference and termination between duplicated $\alpha$-globin gene constructs suggests a novel mechanism for gene regulation. Nature 322: 562-565.

Roberts, S. and D. Bentley. 1992. Distinct modes of transcription readthrough or terminate at the $\mathrm{c}-m y c$ attenuator. EMBO I. 11: 1085-1093.

Shapiro, D., P. Sharp, W. Wahli, and M. Keller. 1988. A high efficiency HeLa nuclear transcription extract. DNA 7:4755.

Spencer, C.A. and M. Groudine. 1990. Transcription elongation and eukaryotic gene regulation. Oncogene 5: 777-785.

Spencer, C., R. Lestrange, W. Hayward, U. Novak, and M. Groudine. 1990. The block to transcription elongation is promoter dependent in normal and Burkitt's lymphoma c-myc alleles. Genes \& Dev. 4: 75-88.

Watson, R. 1988. Expression of the c-myb and c-myc genes is regulated independently in differentiating mouse erythroleukaemia cells by common processes of premature transcription arrest and increased mRNA turnover. Mol. Cell. Biol. 8: 3938-3942.

Whitelaw, E. and N. Proudfoot. 1986. $\alpha$-Thalassaemia caused by a poly(A) site mutation reveals that transcriptional termination is linked to $3^{\prime}$ end processing in the human $\alpha 2$ globin gene. $E M B O$ I. 5: 2915-2922.

Wright, S. and J. Bishop. 1989. DNA sequences that mediate attenuation of transcription from the mouse proto-oncogene c-myc. Proc. Natl. Acad. Sci. 86: 505-509.

Wright, S., L. Mirels, M. Calayag, J. Bishop. 1991. Premature termination of transcription from the $\mathrm{P} 1$ promoter of the mouse c-myc gene. Proc. Natl. Acad. Sci. 8: 11383-11387. 


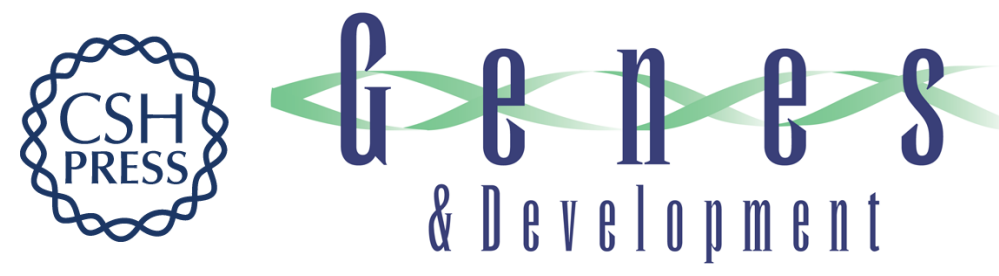

\section{A protein-binding site in the c-myc promoter functions as a terminator of RNA polymerase II transcription.}

S Roberts, T Purton and D L Bentley

Genes Dev. 1992, 6:

Access the most recent version at doi:10.1101/gad.6.8.1562

References This article cites 50 articles, 22 of which can be accessed free at: http://genesdev.cshlp.org/content/6/8/1562.full.html\#ref-list-1

License

Email Alerting

Service

Receive free email alerts when new articles cite this article - sign up in the box at the top right corner of the article or click here.

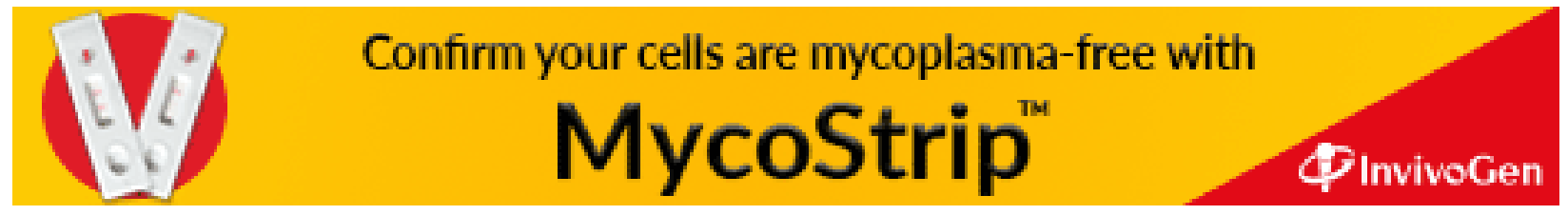

